\title{
Avaliação de dois meios de cultura semi-seletivos para a detecção de Curtobacterium flaccumfaciens pv. flaccumfaciens em sementes de feijoeiro
}

\author{
Maria Heloisa Duarte de Moraes, Vanessa Cristina Frare, Júlia Ronzella Ottoni, Denise Moedim Balani, \\ Vitor Henrique Vaz Mondo \& José Otávio Machado Menten
}

Departamento de Fitopatologia e Nematologia, ESALQ, Universidade de São Paulo, 13418-900, Piracicaba, SP, Brasil

Autor para correspondência: Maria Heloisa Duarte de Moraes, e-mail: mhdmorae@esalq.usp.br

\section{RESUMO}

Comparou-se a eficiência dos meios semi-seletivos MSCFF e CNS modificado para a detecção de Curtobacterium flaccumfaciens pv. flaccumfaciens (Cff) através dos métodos de repicagem por estria e por espalhamento, em sementes de feijoeiro. Duas amostras foram subdivididas em quatro de $500 \mathrm{~g}$ cada, imersas em $600 \mathrm{~mL}$ de água destilada esterilizada, por $18 \mathrm{~h} \mathrm{a} 5^{\circ} \mathrm{C}$, e as suspensões obtidas foram repicadas para ambos os meios. Após incubação das placas a $28^{\circ} \mathrm{C}$ por 72 e 144 horas, procedeu-se à avaliação qualitativa de crescimento de Cff, comparando-se com um isolado padrão. Colônias com características típicas de Cff foram observadas nos dois meios de cultura. Algumas colônias foram purificadas e submetidas à reação de polimerase em cadeia (Bio-PCR), com iniciadores específicos para Cff, e a teste de hipersensibilidade em folhas de fumo. Nas duas avaliações realizadas observou-se crescimento característico de $C f f$ no meio MSCFF, para as amostras de sementes, nos dois métodos de repicagem utilizados. No meio CNS modificado, a bactéria só foi detectada nas amostras de sementes 144 horas após a incubação, independente do método utilizado. Os resultados evidenciaram uma maior rapidez no crescimento de Cff no meio semi-seletivo MSCFF. Os isolados bacterianos foram identificados como Cff através de PCR e reação positiva de hipersensibilidade em fumo.

Palavras-chave: Phaseolus vulgaris, sanidade de sementes, murcha-de-curtobacterium.

\section{ABSTRACT}

Evaluation of two semi-selective media to detect Curtobacterium flaccumfaciens pv. flaccumfaciens in bean seeds

This study aimed to compare the effectiveness of the semi-selective MSCFF and modified CNS culture media in detecting Curtobacterium flaccumfaciens pv. flaccumfaciens (Cff) in bean seeds, using the streak and spread plate techniques. Four $500 \mathrm{~g}$ subsamples, obtained from two samples of bean seeds, were immersed in $600 \mathrm{~mL}$ of sterile distilled water for $18 \mathrm{~h}$ at $5^{\circ} \mathrm{C}$. Suspensions were picked and transferred to plates with both culture media. Plates were then incubated at $28^{\circ} \mathrm{C}$, and bacterial growth on both media was evaluated 72 and 144 hours later, compared to the growth of a Cff reference strain. Both media revealed the presence of Cff colonies. Typical colonies were isolated for PCR analyses and pathogenicity tests on tobacco leaves. A characteristic Cff growth on MSCFF medium was observed for the seed samples, for the two plate techniques used, in both evaluations. On the modified CNS culture medium, the bacterial growth was only detected in seed samples after 144 hours of incubation, regardless of the plate technique used. The results showed $C f f$ grew faster on the MSCFF semi-selective culture medium. Bacterial isolates tested were identified as Cff by both PCR analyses and a positive tobacco hypersensitivity reaction.

Key words: Phaseolus vulgaris, seed health, bacterial wilt.

No Brasil, a cultura do feijão tem grande importância devida a sua participação na dieta alimentar da população e por envolver uma grande área de produção cultivada. Caracteriza-se, também, como uma cultura que apresenta grande incidência de doenças durante o ciclo de desenvolvimento, muitas das quais são transportadas e transmitidas via sementes, sendo assim, fonte para diversos estudos na área de patologia de sementes. Dentre essas doenças, a murcha-de-curtobacterium, causada por Curtobacterium flaccumfaciens pv. flaccumfaciens (Hedges) Collins \& Jones (Cff), assume relevante importância (Saettler, 1991). Essa doença foi constatada pela primeira vez no Brasil em 1995, no Estado de São Paulo (Maringoni \& Rosa, 1997) e, recentemente, nos Estados do Paraná, Santa Catarina,Goiás e Distrito Federal (Leite et al., 2001; Uesugi et al., 2003).

Como principais sintomas desta doença podem ser citados murcha e flacidez dos folíolos durante períodos quentes e secos, normalmente progredindo para a formação de lesões amareladas e necróticas nas folhas e descoloração nas sementes (Hall, 1991). É importante salientar que o principal meio de disseminação desse agente patogênico a longas distâncias é via sementes (Hedges, 1926 citado por Behlau et al., 2006). A bactéria sobrevive em restos 
culturais infectados, em plantas voluntárias no campo, em hospedeiros alternativos (outras leguminosas, como soja, ervilha e caupi) e em sementes (Bianchini et al., 2005). As medidas recomendadas para o controle da murcha-decurtobacterium são rotação de culturas com espécies não suscetíveis, uso de sementes sadias e variedades resistentes (Bianchini et al., 2005), embora o uso de sementes sadias ainda pareça ser a medida de controle mais eficiente (Coelho et al., 2004).

Análises visuais das sementes são insuficientes para determinar a presença ou não de bactérias fitopatogênicas. Deste modo, existe a necessidade de testes que possibilitem detectar bactérias em sementes, especialmente quando o nível de infecção é muito baixo (Oliveira, 1995). Em fitobacteriologia os meios semi-seletivos são considerados uma ferramenta de relevante importância para o diagnóstico de doenças, estudos epidemiológicos e para o isolamento de bactérias fitopatogênicas em tecidos vegetais e/ou sementes (Kruppa, 1993). Dessa forma, o presente trabalho teve por objetivo avaliar a eficiência de dois meios semi-seletivos para a deteç̧ão de Curtobacterium flaccumfaciens pv. flaccumfaciens em sementes de feijão.

Foram utilizadas duas amostras representativas de dois lotes de sementes de feijão cv. Rubi, provenientes de dois campos de produção, no vale do Paranapanema, que apresentaram sintomas de murcha-de-curtobacterium. Cada amostra foi dividida em quatro sub-amostras de $500 \mathrm{~g}$, as quais foram acondicionadas separadamente em erlenmeyers contendo $600 \mathrm{~mL}$ de água destilada e esterilizada, e mantidas a $5^{\circ} \mathrm{C}$ por aproximadamente $18 \mathrm{~h}$. Após esse período, a água foi separada das sementes e uma parte foi levada à centrífuga $(10000 \mathrm{x}$ g/15 min.) em tubos Falcon de $50 \mathrm{~mL}$ de capacidade. Após a centrifugação, o sobrenadante foi descartado e as células foram ressuspendidas em 1,0 $\mathrm{mL}$ de água destilada esterilizada, de forma a conseguir diluições de $10^{-5}, 10^{-6}$ e $10^{-7}$. As formas de repicagem foram por estrias, antes da centrifugação, e por espalhamento com alça de Drigalsky, após centrifugação e ressuspensão, colocando-se um volume de $0,1 \mathrm{~mL}$ para o espalhamento, para cada diluição. A repicagem por estrias foi feita sem que a água separada das sementes fosse centrifugada, uma vez que este é o procedimento mais utilizado em laboratório de rotina devido a sua praticidade e também pelo fato de outros trabalhos utilizarem essa forma de repicagem (Maringoni et al., 2006; Herbes et al., 2008). Foram utilizadas três repetições de duas placas para cada tratamento e, após a instalação do teste, as placas foram mantidas em estufa a $28^{\circ} \mathrm{C}$ e as avaliações foram realizadas após 72 e 144 horas de incubação.

Para a detecção de Cff foram comparados dois meios: MSCFF (meio semi-seletivo para Curtobacterium flaccumfaciens pv. Alaccumfaciens) e CNS modificado (meio semi-seletivo para Clavibacter michiganensis subsp. nebraskensis modificado), descritos por Maringoni et al. (2006) e Behlau et al. (2006), respectivamente. O meio MSCFF é composto por 5,0 g/L de peptona bacteriológica; $3,0 \mathrm{~g} / \mathrm{L}$ de extrato de carne; $5,0 \mathrm{~g} / \mathrm{L}$ de sacarose; $15,0 \mathrm{~g} /$ $\mathrm{L}$ de ágar; $5,0 \mathrm{~g} / \mathrm{L}$ de leite em pó desnatado; $0,05 \mathrm{~g} / \mathrm{L}$ de vermelho congo; $0,01 \mathrm{~g} / \mathrm{L}$ de clorotalonil; $0,01 \mathrm{~g} / \mathrm{L}$ de tiofanato metílico; $0,01 \mathrm{~g} / \mathrm{L}$ de ácido nalidíxico; $0,01 \mathrm{~g} / \mathrm{L}$ de nitrofurantoína; $0,001 \mathrm{~g} / \mathrm{L}$ de oxacilina e $0,001 \mathrm{~g} / \mathrm{L}$ de azida de sódio. O meio CNS modificado é composto de $8,0 \mathrm{~g} / \mathrm{L}$ de caldo nutriente; $2,0 \mathrm{~g} / \mathrm{L}$ de extrato de levedura; $2,0 \mathrm{~g} / \mathrm{L}$ de $\mathrm{K}_{2} \mathrm{HPO}_{4} ; 0,5 \mathrm{~g} / \mathrm{L}$ de $\mathrm{KH}_{2} \mathrm{PO}_{4} ; 10,0 \mathrm{~g} / \mathrm{L}$ de $\mathrm{LiCl}$; $15,0 \mathrm{~g} / \mathrm{L}$ de ágar; $5,0 \mathrm{~g} / \mathrm{L}$ de glicose e $124 \mathrm{mg} / \mathrm{L}$ de sulfato de magnésio anidro. A avaliação consistiu na observação e anotação da presença (+) ou ausência (-) de colônias típicas de $C f f$ que, no meio CNS modificado são lisas, convexas, não viscosas e semi-fluidas, de coloração amarela (Figura 1A), alaranjada ou rosa. Essas mesmas características podem ser observadas no meio MSCFF, além de formação de halo ao redor da colônia devido à degradação da caseína e do vermelho congo (Figura 1B).

Um isolado de cada amostra de sementes, obtidos no meio CNS modificado, suspeitos de serem Cff, foram purificados e submetidos à confirmação, através de reação
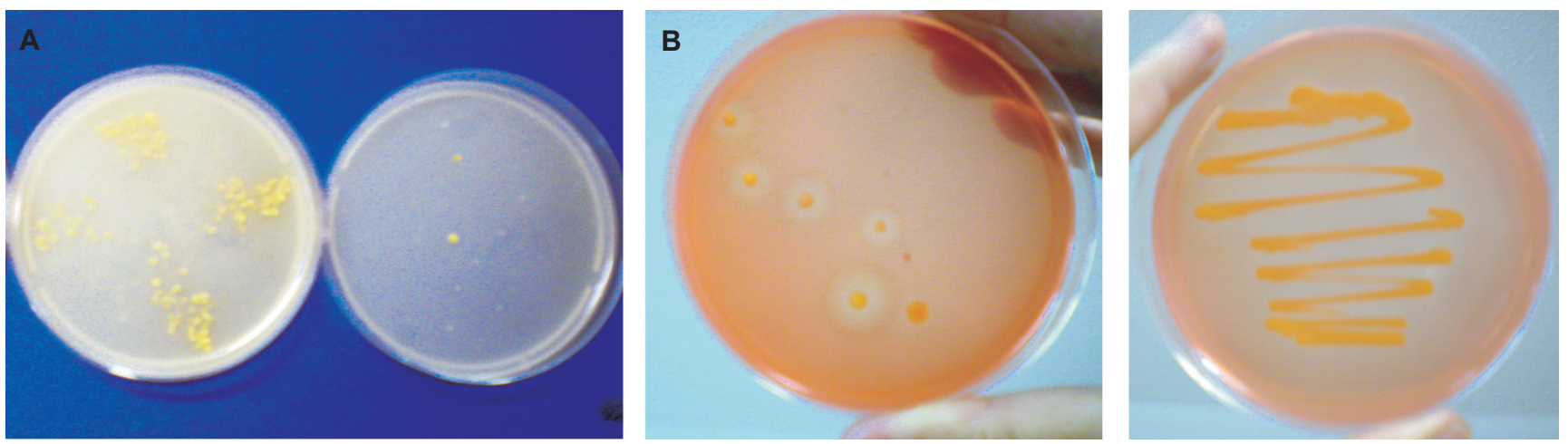

FIGURA 1 - A. Colônias características de Curtobacterium flaccumfaciens pv. flaccumfaciens nos meios CNS modificado e B. "MSCFF" com formação de halo. 
em cadeia da polimerase com iniciadores específicos para Cff (CF4 - 5'CAC AGC CAC CTA CAT GC 3' e CF5 GAT CGG GAG TCC GAG 3'), descritos por Guimarães et al. (2001), e através de teste de hipersensibilidade em folhas de fumo. A identificação molecular foi realizada com base no protocolo descrito por Guimarães et al. (2001) com modificações, e para as reações foram utilizadas amostras sem prévia extração de DNA (Bio-PCR). Para cada reação foram utilizados $2,0 \mu \mathrm{L}$ da cultura bacteriana crescida em caldo nutriente a $28^{\circ} \mathrm{C}, 2,0 \mu \mathrm{L}$ de buffer, $1,2 \mu \mathrm{L}$ de $\mathrm{MgCl}_{2}$ $25 \mathrm{mM}, 0,4 \mu \mathrm{L}$ de dNTP $10 \mathrm{mM}, 0,5 \mu \mathrm{L}$ de cada iniciador $(20 \mathrm{mM}), 0,2 \mu \mathrm{L}$ de Taq DNA Polimerase $(5 \mathrm{U} / \mu \mathrm{L})$ e $12,4 \mu \mathrm{L}$ de água Milli $Q$ esterilizada. As reações consistiram de um ciclo de desnaturação a $96^{\circ} \mathrm{C}$ por 30 segundos, anelamento a $55^{\circ} \mathrm{C}$ por 30 segundos e extensão a $72^{\circ} \mathrm{C}$ por 30 segundos, com um ciclo final de extensão a $72^{\circ} \mathrm{C}$ por 10 minutos. A eletroforese foi conduzida em gel de agarose 1\% com Sybr Safe. O controle positivo foi composto pela suspensão do isolado IBSBF 853 (= NCPPB 559). Para o controle negativo utilizou-se 2,0 $\mu \mathrm{L}$ de água Milli Q esterilizada.

Para o teste de hipersensibilidade em folhas de fumo os isolados, na forma de suspensão obtida de colônia crescida em meio nutriente-ágar a $28^{\circ} \mathrm{C}$, foram inoculados por pressão com ajuda de uma seringa hipodérmica; a testemunha foi inoculada com água esterilizada. As plantas foram mantidas em casa de vegetação e a avaliação foi feita após 24 e 48 horas da inoculação (Romeiro, 2001). Os dois meios utilizados foram eficientes na detecção de $C f f$, pelos dois métodos de repicagem, como se pode observar nas Tabelas 1 e 2 . No método da repicagem através de estrias (Tabela 1), para a amostra 1, observou-se crescimento típico da bactéria 72 horas após a repicagem, em todas as repetições do meio MSCFF, e após 144 horas para os dois meios. Para a amostra 2 o mesmo se repetiu para o meio MSCFF, enquanto que no meio CNS modificado observouse crescimento também após 72 horas, mas apenas em duas repetições.

Através da repicagem por espalhamento com alça de Drigalsky (Tabela 2), observou-se, praticamente, o mesmo comportamento que no método anterior. Para as amostras 1 e 2, no meio CNS modificado, não se observou crescimento na primeira avaliação, mas 144 horas após a repicagem o teste foi positivo nas três concentrações, em pelo menos duas repetições de cada concentração, para a amostra 1; para a amostra 2 detectou-se apenas em três repetições da maior concentração $\left(10^{-5}\right)$. O meio MSCFF mostrou crescimento típico da bactéria em praticamente todas as repetições das três concentrações, nas duas amostras avaliadas, a partir da primeira avaliação. Apenas duas repetições da amostra 2 deram resultado negativo, ambas para a diluição de $10^{-7}$.

Esse resultado não corrobora o obtido por Mehta et al. (2005) para detecção de Xanthomonas axonopodis pv. malvacearum em sementes de algodão. Os autores compararam os métodos de semeio das sementes em meio semi-seletivo, inoculação de plântulas suscetíveis com suspensão obtida da imersão das sementes em solução salina e "growing on" em casa de vegetação, concluindo que o semeio em meio semi-seletivo foi mais eficiente em detectar baixos níveis de incidência da bactéria em sementes de diferentes lotes. Porém, é inviável a utilização dessa metodologia em laboratório de rotina pelo fato de ser necessária a utilização de um grande número de placas de Petri para se avaliar 2.000 sementes por lote, como sugerido pelos autores. Além do mais, a avaliação só foi possível após sete-12 dias de incubação das placas. A identificação dos isolados bacterianos foi confirmada pela Bio-PCR e a patogenicidade pelo teste de hipersensibilidade em folhas de fumo (Figura 2).

De acordo com Klement et al. (1990), os dois principais critérios para a avaliação de um meio semiseletivo são a sua eficiência na detecção e sua seletividade. Durante as avaliações foram feitas observações importantes para auxiliar na escolha do meio de cultura e do método de repicagem. A repicagem por espalhamento com a alça de Drigalsky proporcionou, no meio MSCFF, o crescimento de colônias tanto da bactéria alvo quanto de bactérias oportunistas também presentes nas sementes, enquanto que no meio CNS modificado foi observado apenas o crescimento da bactéria alvo. Estes resultados estão de acordo com os obtidos por Maringoni et al. (2006) e Behlau et al. (2006) para os meios MSCFF e CNS modificado, respectivamente. Ao testar o meio MSCFF os autores observaram que o crescimento de 9 dos 14 isolados de bactérias saprofíticas, obtidas de sementes de feijão, foi

TABELA 1 - Detecção de Curtobacterium flaccumfaciens pv. flaccumfaciens, pelo método de repicagem por estria, em dois meios semiseletivos (CNS modificado e MSCFF), em duas amostras de sementes de feijão

\begin{tabular}{|c|c|c|c|c|c|c|c|c|}
\hline & \multicolumn{4}{|c|}{ Meio CNS modificado } & \multicolumn{4}{|c|}{ Meio MSCFF } \\
\hline & \multicolumn{2}{|c|}{ Amostra 1} & \multicolumn{2}{|c|}{ Amostra 2} & \multicolumn{2}{|c|}{ Amostra 1} & \multicolumn{2}{|c|}{ Amostra 2} \\
\hline & $72 \mathrm{hr}$ & $144 \mathrm{hr}$ & $72 \mathrm{hr}$ & $144 \mathrm{hr}$ & $72 \mathrm{hr}$ & $144 \mathrm{hr}$ & $72 \mathrm{hr}$ & $144 \mathrm{hr}$ \\
\hline Rep. A & - & + & + & + & + & + & + & + \\
\hline Rep. B & - & + & + & + & + & + & + & + \\
\hline Rep. C & - & + & - & + & + & + & + & + \\
\hline Rep. D & - & + & - & + & + & + & + & + \\
\hline
\end{tabular}

+ crescimento de colônia típica; - ausência de crescimento de colônia típica. 
TABELA 2 - Detecção de Curtobacterium flaccumfaciens pv. flaccumfaciens, pelo método de repicagem por espalhamento, em dois meios semi-seletivos (CNS modificado e MSCFF), em duas amostras de sementes de feijão

\begin{tabular}{|c|c|c|c|c|c|c|c|c|c|}
\hline & \multirow[b]{3}{*}{ Repetição } & \multicolumn{4}{|c|}{ MEIO CNS modificado } & \multicolumn{4}{|c|}{ MEIO MSCFF } \\
\hline & & \multicolumn{2}{|c|}{ Amostra 1} & \multicolumn{2}{|c|}{ Amostra 2} & \multicolumn{2}{|c|}{ Amostra 1} & \multicolumn{2}{|c|}{ Amostra 2} \\
\hline & & $72 \mathrm{~h}$ & $144 \mathrm{~h}$ & $72 \mathrm{~h}$ & $144 \mathrm{~h}$ & $72 \mathrm{~h}$ & $144 \mathrm{~h}$ & $72 \mathrm{~h}$ & $144 \mathrm{~h}$ \\
\hline \multirow[t]{4}{*}{$10^{-5}$} & A & - & - & - & + & + & + & + & + \\
\hline & B & - & + & - & + & + & + & + & + \\
\hline & $\mathrm{C}$ & - & + & - & - & + & + & + & + \\
\hline & $\mathrm{D}$ & - & + & - & + & + & + & + & + \\
\hline \multirow[t]{4}{*}{$10^{-6}$} & A & - & - & - & - & + & + & + & + \\
\hline & B & - & - & - & - & + & + & + & + \\
\hline & $\mathrm{C}$ & - & + & - & - & + & + & + & + \\
\hline & $\mathrm{D}$ & - & + & - & - & + & + & + & + \\
\hline \multirow[t]{4}{*}{$10^{-7}$} & A & - & - & - & - & + & + & - & + \\
\hline & B & - & + & - & - & + & + & + & + \\
\hline & $\mathrm{C}$ & - & + & - & - & + & + & - & + \\
\hline & $\mathrm{D}$ & - & - & - & - & + & + & + & + \\
\hline
\end{tabular}

+ crescimento de colônia típica; - ausência de crescimento de colônia típica.
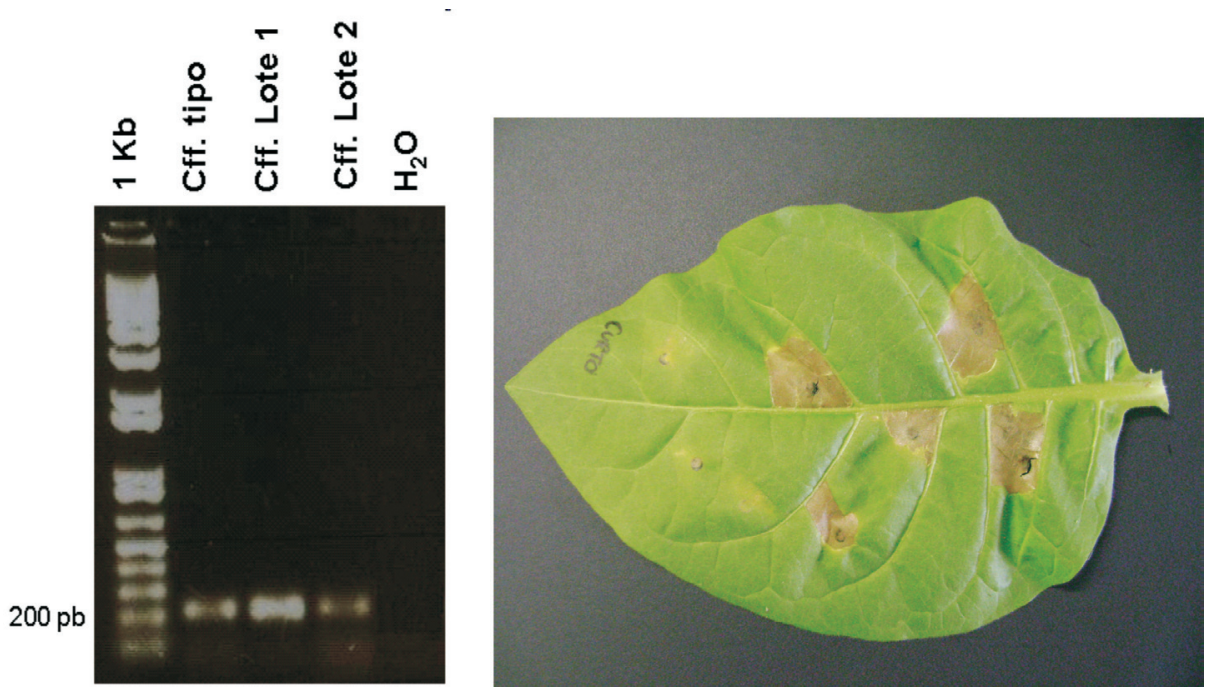

FIGURA 2 - A. Bio-PCR positiva para os isolados de Curtobacterium flaccumfaciens pv. flaccumfaciens obtidos das duas amostras de sementes de feijão, no meio CNS modificado, e para o isolado testemunha; B. reação de hipersensibilidade em folha de fumo após infiltração de três isolados obtidos.

inibido enquanto que nenhuma inibição foi observada para os isolados de Cff. Quanto ao meio CNS modificado, Behlau et al. (2006) constataram alta especificidade para Cff, não sendo observado crescimento de outros gêneros de fitobactérias testados.

Devido à grande quantidade de microrganismos que constituem a flora microbiana associada a sementes, o uso de meios semi-seletivos só é eficiente quando este apresenta efetiva seletividade, alta supressão para microrganismos saprófitas e baixo índice de repressão para a bactéria fitopatogênica em análise (Romeiro, 2001). Além disso, para a avaliação criteriosa de um método para a detecção de agente patogênico, deve ser levada em consideração características básicas como a praticidade, rapidez na obtenção de resultados, custo, facilidade para análise, identificação e, se necessário, isolamento do microrganismo (Denardin et al., 2004).

O meio de cultura denominado MSCFF pode ser utilizado em análises de rotina para detecção de Cff em sementes de feijão, pela facilidade de elaboração, pela rapidez de detecção e também pelo baixo custo, concordando com Maringoni et al. (2006). Este meio tem sido utilizado com sucesso na detecção de Cff em amostras de sementes de feijão produzidas em Santa Catarina (Herbes et al., 2008) e de outras regiões (Maringoni \& Camara, 2006). Os resultados obtidos na análise molecular (Bio-PCR) e no teste de hipersensibilidade em folhas de fumo foram importantes para a confirmação da efetividade dos meios de cultura testados, uma vez que os diferentes métodos de avaliação de um mesmo alvo obtiveram resultados semelhantes, 
aumentando a credibilidade das conclusões observadas no estudo e endossando a eficiência dos meios pesquisados.

\section{REFERÊNCIAS BIBLIOGRÁFICAS}

Behlau F, Nunes LM, Leite Junior RP (2006) Meio de cultura semi-seletivo para detecção de Curtobacterium flaccumfaciens pv. flaccumfaciens em solo e sementes de feijoeiro. Summa Phytopathologica 32:394-396.

Bianchini A, Maringoni AC, Carneiro SMTPG (2005) Doenças do feijoeiro. In: Kimati H, Amorim L, Rezende JAM, Bergamin Filho A, Camargo LEA (Eds.) Manual de Fitopatologia: doenças de plantas cultivadas. 4 ed. São Paulo SP. Agronômica Ceres. pp. 333-349.

Coelho MVS, Guimarães PM, Marques ASA, Martins OM (2004) Curtobacterium flaccumfaciens pv. flaccumfaciens. Murcha bacteriana do feijoeiro e da soja: alto risco de disseminação no Brasil. Comunicado Técnico 117. Disponível em <http://www. cenargen.embrapa.br/publica/trabalhos/cot117.pdf $>$

Denardin ND, Moura AB, Menten JOM (2004) Detecção e identificação de bactérias em sementes. In: Anais, 8. Simpósio Brasileiro de Patologia de Sementes, João Pessoa PB. pp. 62-67.

Guimarães PM, Palmano S, Smith JJ, Sa MFG, Sadler GS (2001) Development of PCR test for detection of Curtobacterium flaccumfaciens pv. flaccumfaciens. Antonie van Leeuwenhoek 80:1-10.

Hall R (1991) Compendium of bean diseases. Saint Paul MN. APS Press.

Herbes DH, Theodoro GF, Maringoni AC, Piva CA, Abreu L (2008) Detecção de Curtobacterium flaccumfaciens pv. flaccumfaciens em sementes de feijoeiro produzidas em Santa Catarina. Tropical Plant Pathology 33:153-156.

Klement Z, Rudolph K, Sands DC (1990) Methods in phytobacteriology. Budapest. Akademiai Kiadó.
Kruppa PC (1993). Detecção de Xanthomonas campestris pv. vesicatoria em sementes e no interior de frutos de tomateiro pelo uso de meios de culturas semi-seletivos.. Dissertação de Mestrado. Universidade Estadual Paulista. Botucatu SP.

Leite Jr. RP, Meneguim L, Behlau F, Rodrigues SR, Bianchini A (2001). Ocorrência de Curtobacterium flaccumfaciens pv. Alaccumfaciens em feijoeiro no Paraná e Santa Catarina. Fitopatologia Brasileira 26 (Supl.):303-304.

Maringoni AC, Camara RC (2006) Curtobacterium flaccumfaciens pv. flaccumfaciens detection in bean seeds using a semi-selective medium. Brazilian Journal of Microbiology 37:451-455

Maringoni AC, Camara RC, Souza VL (2006) Semi-selective culture medium for Curtobacterium flaccumfaciens pv. flaccumfaciens isolation from bean seeds. Seed Science \& Technology 34:117-124.

Maringoni AC, Rosa EF (1997) Ocorrência de Curtobacterium flaccumfaciens pv. flaccumfaciens em feijoeiro no estado de São Paulo. Summa Phytopathologica 23:160-162.

Mehta YR, Bomfeti C, Bolognini V (2005) A semi-selective agar medium to detect the presence of Xanthomonas axonopodis pv. malvacearum in naturally infected cotton seeds. Fitopatologia Brasileira 30:489-496.

Oliveira JR (1995) Detecção de Xanthomonas campestris pv. vesicatoria em sementes de tomateiro. Tese de Doutorado. Viçosa MG. Universidade Federal de Viçosa.

Romeiro RS (2001) Métodos em Bacteriologia de Plantas. Viçosa MG. Universidade Federal de Viçosa.

Saettler AW (1991) Diseases caused by bacteria. In: Hall R (Ed.) Compendium of bean diseases. Saint Paul MN. APS Press. pp. 29-32.

Uesugi CH, Freitas MA, Menezes JR (2003) Ocorrência de Curtobacterium flaccumfaciens pv. flaccumfaciens em feijoeiro em Goiás e Distrito Federal. Fitopatologia Brasileira 28:324. 